\title{
PEMBERDAYAAN DAN PERLINDUNGAN HUKUM BAGI KONSUMEN DALAM RANGKA MELINDUNGI KEPENTINGAN KONSUMEN KURANG MAMPU
}

\author{
Suraji, Pranoto \\ Fakultas Hukum Universitas Sebelas Maret Surakarta \\ e-mail : suraji1961@yahoo.com; maspran7@gmail.com
}

\begin{abstract}
This research proposed to identify consumer weakness in solving of dispute with businessman; identify and describe consumer effort in solving of dispute with businessman. It was empirical research which used qualitatively and descriptively method. This research used primary data perceived from interview result and secondary data perceived from act, literature, document and Lp2K's brochure. Data collection was done by field observation and bibliography. And then, the datum would analyzed by qualitatively and interactively model. The result of the research showed some conditions influenced consumer weakness when faced businessman. Firstly, when faced businessman from State-Owned corporation and Local corporation: (1) because State-Owned corporation stronger than consumer; (2) State-Owned corporation and Local corporation always dodged to give compensation to consumer when they were loss out; (3) businessman was represented by their staff and could not make direct decision; (4) businessman always prolonged time to construct team for compensation investigation; (5) businessman usually recovery, continue and live on without give compensation according the agreement. Secondly, when faced private businessman: (1) businessman compensated lowest amount only; (2) businessman said that only their rule was obedient. consumer endeavor could run by two sides: Firstly, from consumer themselves: (1) improvement of legal communication among consumer; (2) improvement of legal understanding generally; (3) understanding of Consumerism Law. Secondly, influence of outsider: (1) legal extension; (2) talk show; (3) letters from readers; (4) consumer education; (5) seminar about consumerism law; and (6) press broadcast.
\end{abstract}

Keywords: consumer endeavor, solving of dispute.

\begin{abstract}
Abstrak
Penelitian ini bertujuan untuk mengidentifikasi ketidakberdayaan konsumen dalam menyelesaikan sengketa dengan pelaku usaha serta mengidentifikasi dan mendeskripsikan upaya-upaya yang dapat ditempuh oleh konsumen dalam rangka penyelesaian sengketa dengan pelaku usaha. Penelitian ini merupakan penelitian empiris dengan metode kualitatif yang bersifat deskriptif. Penelitian menggunakan data primer yang diperoleh dari hasil wawancara dengan informan, maupun data sekunder yang diperoleh dari peraturan perundang-undangan, literatur, dokumen-dokumen dan brosur-brosur dari LP2K. Pengumpulan data dilakukan dengan penelitian lapangan dan kepustakaan. Selanjutnya data akan dianalisis secara kualitatif dengan model interaktif. Hasil penelitian menunjukkan, terdapat beberapa kondisi yang menyebabkan konsumen tidak berdaya ketika berhadapan dengan pelaku usaha. pertama, ketika berhadapan dengan pelaku usaha BUMN dan Perusahaan Daerah : (1) karena posisi BUMN lebih kuat dibandingkan dengan konsumen, (2) BUMN dan Perusda selalu berkelit untuk memberi ganti rugi kepada konsumen apabila terjadi kerugian yang menimpa konsumen, (3) pelaku usaha hanya diwakili oleh stafnya sehingga tidak berani memutus secara langsung, (4) pelaku usaha selalu mengulur waktu bahwa ia akan membentuk tim pengkaji ganti rugi, (5) pelaku usaha biasanya hanya sanggup memperbaiki, menyambung atau menghidupkan lagi tanpa mau mengganti sesuai perjanjian. Kedua, ketika berhadapan dengan pelaku usaha swasta : (1) pelaku usaha hanya mau mengganti kerugian sekecil mungkin, (2) pelaku usaha berdalih bahwa aturan yang dibuatnya itulah yang harus dipatuhi. Upaya pemberdayaan konsumen dapat ditempuh melalui dua sisi, pertama, dari diri konsumen : (1) perlunya peningkatan komunikasi hukum konsumen, (2) peningkatan pemahaman hukum secara umum, (3) pemahaman Undang-undang Perlindungan Konsumen. Kedua, pengaruh pihak luar : (1) penyuluhan hukum, (2) acara dengar pendapat (talkshow), (3) surat pembaca, (4) pendidikan konsumen, (5) seminar hukum perlindungan konsumen, dan (6) siaran pers.
\end{abstract}

Kata Kunci : pemberdayaan konsumen, penyelesaian sengketa. 


\section{A. Pendahuluan}

Kesenjangan ekonomi yang terjadi ditengahtengah masyarakat dapat merugikan berbagai pihak. Masyarakat Indonesia yang tak lain adalah konsumen, paling dirugikan (Yusuf Shofie, 2000 : 1). Dalam era sekarang ini, semua orang dapat dikategorikan sebagai masyarakat modern, yakni masyarakat konsumen, sebab semua orang dalam satu atau lain bentuk tanpa kecuali adalah konsumen dari salah satu barang yang diperoleh melalui kegiatan bisnis (A. Sonny Keraf, 1998 : 181).

Dalam kegiatan bisnis terdapat hubungan yang saling membutuhkan antara produsen dengan konsumen (A. Zen Purba, 1992). Hubungantersebut merupakan hubungan yang terus menerus dan berkesinambungan. Hubungan terjadi karena keduanya saling menghendaki dan mempunyai tingkat ketergantungan yang cukup tinggi (Sri Redjeki Hartono, 2000 : 80; Husni Syawali \& Neni Sri Imaniyati ed, 2000 : 36; Sanusi Bintang dan Dahlan, 2000 : 107; juga Abdul Halim Barkatullah, 2010 : 14). Kepentingan produsen adalah memperoleh laba dari transaksi dengan konsumen, sedangkan kepentingan konsumen adalah memperoleh kepuasan melalui pemenuhan kebutuhannya terhadap produk tertentu (Bilson Simamora, 2001 : 154). Namun demikian, tidak menutup kemungkinan munculnya dampak negatif yang dirasakan konsumen. Akibatnya muncul sengketa antara konsumen dengan pelaku usaha.

Sengketa yang muncul antara konsumen dengan pelaku usaha bermula dari aduan konsumen yang masuk ke Lembaga Perlindungan Konsumen Swadaya Masya-rakat, yang dapat dikategorikan ke dalam beberapa bidang atau golongan komoditi, misalnya : peralatan rumah tangga; makanan dan minuman; iklan/promosi/ undian; perumahan; produk elektronik; kendaraan dan suku cadang; produksi sandang; obat dan kosmetik; pelayanan medik; listrik (Perusahaan Listrik Negara/PLN); telepon (PT Telekomunikasi/ Telkom); air minum (Perusahaan Daerah Air Minum/PDAM); jasa transportasi; jasa perbankan/ asuransi; jasa pos/paket; jasa service; dan jasa lain-lain.

Dari beberapa golongan komoditi aduan tersebut di atas, dalam beberapa kasus diperlukan penyelesaian yang serius, terutama terhadap kasus-kasus yang berhubungan langsung dengan konsumen atau warga masyarakat pada umumnya, seperti listrik, telepon, dan air minum. Oleh karena itu, pemberdayaan konsumen dalam penelitian ini akan difokuskan pada tiga golongan pengaduan yang setiap hari selalu berhubungan langsung dengan masyarakat konsumen, yakni penyelesaian kasus atau pengaduan listrik (PLN), telepon (PT Telkom), dan air minum (PDAM). Penelitian terdahulu (Suraji, 2001 dan 2011) mencatat, bahwa ketiga kasus pengaduan tersebut merupakan pengaduan yang paling banyak diadukan oleh konsumen untuk diselesaikan kepada pelaku usaha. Secara umum penyelesaian kasus ini melibatkan tiga pihak, yakni konsumen, pelaku usaha, dan pihak ketiga.

Bentuk sengketa yang memerlukan penyelesaian antara konsumen dengan pelaku usaha, misalnya dalam kasus atau pengaduan listrik: sering matinya saluran listrik/oglangan, jumlah angka meter terbayar tidak sama dengan pemakaian; kasus aduan telepon : penyedotan pulsa, pembayaran pulsa telepon yang tidak sama dengan riil pemakaian; dan kasus aduan air minum : pembayaran angka meter yang tidak sama dengan riil pemakaian, sering matinya saluran air minum. Terjadinya sengketa perlu dihindari untuk menjaga reputasi dan relasi yang baik. Namun demikian sengketa kadang-kadang tidak dapat dihindari karena adanya kesalahpahaman, pelanggaran perundang-undangan, ingkar janji, kepentingan yang berlawanan, dan/atau kerugian pada salah satu pihak. Dalam beberapa kasus tersebut, nampak betapa kedudukan konsumen demikian lemahnya dibandingkan dengan pelaku usaha.

Yayasan Lembaga Konsumen Indonesia (YLKI) dan Lembaga Pembinaan dan Perlindungan Konsumen (LP2K), sebagai bagian dari Lembaga Perlindungan Konsumen Swadaya Masyarakat (LPKSM) mempunyai kepedulian yang sangat tinggi dalam menyelesaikan sengketa konsumen, dan diharapkan banyak member harapan terhadap upaya mewujudkan pemberdayaan konsumen yang menjadi impian UUPK (Ahmadi Miru dan Sutarman Yodo, 2004 : 17). Temuan awal di LP2K ternyata banyak sekali konsumen yang menggunakan jasa lembaga ini untuk menyelesaikan sengketa dengan pelaku usaha. Di sini konsumen tidak melakukannya lewat jalur pengadilan, melainkan melalui jalur di luar pengadilan.

Faktor utama yang menjadi kelemahan konsumen adalah tingkat kesadaran konsumen akan haknya masih rendah serta masih kurang memadai peraturan perundang-undangan untuk menyetarakan posisi tawar konsumen dengan pelaku usaha dan menjamin hak-hak konsumen 
(Abdul Halim Barkatullah, 2009 : 17; Juga Penjelasan Umum UU No. 9 Tahun 1999). Posisi tawar yang lemah dalam hal kemampuan ekonomi dan upaya hukum konsumen dalam mempertahankan hak-haknya, mengakibatkan konsumen menjadi obyek aktivitas bisnis untuk meraup keuntungan yang sebesar-besarnya oleh pelaku usaha melalui kiat iklan, promosi, cara penjualan, serta penerapan perjanjian standar yang merugikan konsumen (Adrian Sutendi, 2008

: 1). Bahkan kelemahan konsumen ini semakin terasa di tengah semakin meningkatnya teknologi pemasaran (NHT Siahaan, 2005, 14).

Secara makro, ketidakberdayaan konsumen dalam menghadapi pelaku usaha dapat dilihat dari berbagai sisi, yakni :pertama, dari sisi konsumen itu sendiri, misalnya ketidakberdayaandalam bidang ekonomi, tingkat pendidikan, dan daya tawar sebagai faktor internal; kedua, dari sisi pelaku usaha dan kondisi hukum yang memayunginyasebagai faktor eksternal; dan ketiga, peran negara atau pemerintah dalam perlindungan konsumen yang belum sepenuhnya berpihak kepada konsumen.

Pada masa pemerintahan orde baru,kenyataan menunjukkan masih sangat eratnya hubungan antara penguasa atau eksekutif, pengusaha atau dunia usaha, dan kekuasaan legislatif atau wakil rakyat. Harus diakui bahwa penguasa masih berpihak kepada pengusaha. Bahkan ketika naskah akademik UUPK diajukan oleh lembaga swasta (YLKI), baik eksekutif maupun legislatif masih juga belum peduli, apalagi menerima dengan tangan terbuka untuk dibahas menjadi rancangan undang-undang.

Setelah UUPK Iahir, ternyata sikap pemerintahpun masih dirasa belum maksimal dalam melindungi kepentingan konsumen. Terbukti masih sangat lambannya pembentukan perangkat-perangkat yang dibutuhkan dalam kaitan melindungi konsumen, misalnya belum maksimalnya upaya sosialisasi terhadap UUPK, belum dapat dibentuknya BPSK di masingmasing kota atau kabupaten, bahkan masih diketemukannya beberapa kelemahan esensial dari materi UUPK itu sendiri.

Dengan kata lain, pada tataran implementasi, UUPK masih mengalami berbagai kendala, antara lain : “(1) pelaksanaan UUPK dan peraturan pelaksanaannya belum berjalan secara simultan dan komprehensif, seolah-olah antar departemen berjalan sendiri-sendiri, tidak ada keterpaduan; (2) peraturan yang bersifat sektoral tentang perlindungan konsumen terkadang bertentangan antara satu dengan yang lain, tidak saling sinergi, dan terkadang bertolak belakang; dan (3) masih banyak aparat penegak hukum yang belum memahami substansi UUPK, bahkan respon masyarakat konsumen dan produsen terhadap UUPK masih rendah."(M. Ali Mansyur, 2007 : 11-12).

Upaya pemberdayaan konsumen terkait dengan perumusan kebijakan, standar, norma, kriteria dan prosedur, bimbingan teknis, serta evaluasi pelaksanaan di bidang kerjasama, informasi dan publikasi pemberdayaan konsumen, analisis penyelenggaraan pemberdayaan konsumen, bimbingan konsumen dan pelaku usaha, pelayanan pengaduan serta fasilitasi kelembagaan perlindungan konsumen.

Berdasarkan uraian atau kondisi di atasdapat disimpulkan,bahwa masih diperlukan beberapa upaya pemberdayaan konsumen secara komprehensif melalui tiga pihak, yakni konsumen, pelaku usaha, dan negara atau pemerintah atau pihak ketiga.Artinya, dalam pemberdayaan konsumen, selain oleh diri konsumen itu sendiri, adalah juga menjadi tanggung jawab produsen (pelaku usaha) dan negara atau pemerintah atau pihak ketiga, sekalipun dalam penelitian ini masih menitikberatkan pada pemberdayaan dari sisi konsumen terlebih dahulu

Oleh karena posisi konsumen yang lebih lemah itulah perlu dicarikan formula dalam rangka lebih meningkatkan posisi tawar atau memberdayakan konsumen. Atas dasar uraian tersebut di atas, penelitian ini akan menyoroti permasalahan faktor-faktor yang menyebabkan konsumen tidak berdaya ketika berhadapan dengan pelaku usaha,danupaya yang dapat ditempuh agar konsumen lebih berdaya ketika menyelesaikan sengketa dengan pelaku usaha.

\section{B. Metode Penelitian}

Dari sifatnya, penelitian ini merupakan penelitian deskriptif analitis. Dari perspektif metode penelitian hukum, law in action diimplementasikan ke dalam paradigma penelitian hukum non doktrinal (Bambang Sunggono, 2011 : 101). Dengan metode kualitatif diharapkan akan ditentukan makna-makna yang tersembunyi di balik obyek maupun subyek yang diteliti (Esmi Warassih, $1999: 47$ ).

Penelitian ini menggunakan data primer dan data sekunder. Untuk memperoleh informasi yang lengkap, dipilih beberapa pihak, misalnya : 
(a) Konsumen dari berbagai produk barang dan jasa; (b) Pelaku usaha yang pernah bermasalah dengan konsumen; (c) Aktifitas Lembaga Swadaya Masyarakat yang bergerak dalam upaya perlindungan konsumen.

Penentuan informan dilakukan secara purposive sampling, sesuai kepentingan dan keperluan dalam menganalisis perkembangan informasi maupun sumbernya yang dapat berkembang mengikuti prinsip bola salju (snow ball), dan pilihan sampel berakhir apabila terdapat indikasi sudah tidak ada lagi informasi yang dapat diperoleh, dan validitas informasi sudah dirasa cukup untuk kepentingan analisis data.

Pengumpulan data ditempuh melalui beberapa cara. pertama, pada saat pra survey, dilakukan pengambilan data awal di instansi terkait. Kedua, wawancara (interview) (Lexy J Moleong, 2005 : 135). Wawancara tidak dilakukan secara terarah (non directive interview). Ketiga, observasi di lapangan ketika sedang berlangsung proses penyelesaian sengketa. Ke-empat, studi pustaka (library research) yakni menggali berbagai dokumen dari data sekunder yang berasal dari bahan hukum primer, bahan hukum sekunder dan bahan hukum tersier.

Pengolahan data menggunakan pendekatan kualitatif, sedangkan analisisnya menggunakan model interaktif (interactive model of analysis). Proses analisis interaktif adalah ketika pengumpulan data selalu diikuti dengan membuat reduksi data dan sajian data (HB Sutopo, 1990 : 11; Miles dan Huberman, 1992 : 20; M. Djunaidi Ghony dan Fauzan Almanshur, 2012 : 308; Djam'an Satori \& Aan Komariah, 2012 : 218; Sugiyono (I), 2012 : 92, juga Sugiyono (II), 2012 : 247)).

\section{Hasil Penelitian dan Pembahasan}

Pembahasan berikut difokuskan pada dua tema pokok utama sesuai dengan rumusan masalah dan tujuan penelitian, yakni : pertama, fakta-fakta yang menunjukkan ketidakberdayaan konsumen ketika berhadapan dengan pelaku usaha; kedua, upaya-upaya pemberdayaan konsumen dalam penyelesaian sengketa konsumen.

\section{Ketidakberdayaan Konsumen Ketika Berhadapan dengan Pelaku Usaha}

Ketidakberdayaan bukan menunjuk pada tidak adanya kekuatan sama sekali. Chambers (1983 : 210-214) menyatakan, bahwa situasi ketidakberdayaan dapat diatasi dengan :"... enabling and empowering the poor through 'reversals in management' of dominant paradigms of development which involves shiftings power and initiatives downwards and outwards. 'Dalam realitas, mereka yang tampaknya hanya memiliki sedikit kekuatan ternyata justru mampu untuk bertahan, menggulingkan dan kadangkadang mentransformasikan kondisi hidup mereka. Kekuatan ini sebenarnya ada, namun masih perlu ditampakkan dan dikembangkan.

Upaya terpenting adalah bagaimana dapat memberdayakan para konsumen sebagai pihak yang sangat potensial menderita kerugian dalam menghadapi pelaku usaha, agar di kemudian hari hakhaknya tidak dilanggar oleh pelaku usaha. Pada kenyataannya konsumen memang merupakan pihak yang harus dilindungi, karena bagaimanapun juga sebagai pihak yang berada pada posisi tawar yang rendah atau lebih lemah jika dibandingkan dengan pelaku usaha mereka patut untuk mendapatkan perlindungan.

Ketidak berdayaan konsumen dapat dikategorikan sebagai berikut :

a. Ketika berhadapan dengan pelaku usaha Badan Usaha Milik Negara (BUMN) dan Perusahaan Daerah :

1) PT Telkom sebagai suatu BUMN - sekarang kepemilikan asing merupakan pelaku usaha yang mempunyai posisi atau kedudukan lebih kuat jika dibandingkan dengan posisi konsumen. Karena posisi yang demikian kuat itulah pada umumnya mereka akan sedapat mungkin membuat aturan-aturan yang ditetapkan secara sepihak tanpa melibatkan pihak konsumen, sehingga dalam menetapkan isiisi perjanjiannya mereka akan berusaha menguntungkan diri sendiri, dan sejauh mungkin akan berusaha melimpahkan tanggungjawab kepada konsumen (dengan menetapkan syarat-syarat eksonerasi). Kondisi demikian dapat disejajarkan dan dapat tercipta oleh karena pelaku usaha menetapkan syarat-syarat baku di dalam perjanjian baku. Isinya bertujuan untuk melindungi kepentingan pelaku usaha dan dalam pembuatannya tidak membutuhkan dan tidak ada persetujuan konsumen. 
2) Pelaku usaha BUMN dan Perusahaan Daerah sedapat mungkin berkelit untuk memberikan ganti rugi apabila terjadi kerugian yang menimpa konsumen dengan alasan bahwa peraturan yang ada (dan dibuatnya) tidak mengaturnya. Peraturan yang ada tidak memuat tentang besarnya ganti kerugian oleh karena pada saat pembuatannya memang tidak dipersiapkan untuk itu, sehingga dalil-dalil konsumen untuk menuntut ganti kerugian tidak kuat. Lagi pula pelaku usaha dengan posisinya yang kuat akan berusaha mengulurulur waktu dan balik mem-pressure konsumen.

3) Ketika berlangsung upaya penyelesaian sengketa dengan jalur mediasi, pelaku usaha biasanya hanya diwakili oleh staff yang bertindak untuk dan atas nama perusahaan. Namun demikian, ketika penyelesaian sengketa telah mendekati final dan konsumen menuntut ganti kerugian, wakil tersebut tidak berani memutus secara langsung. Biasanya ia minta waktu lagi dengan alasan tuntutan konsumen (sebesar) ini akan dikonsultasikan dengan atasan terlebih dahulu. Inilah yang menyebabkan mundurnya waktu penyelesaian sengketa dari waktu yang semestinya.

4) Pelaku usaha berusaha mengulurulur waktu atau upaya penyelesaian sengketa dan tuntutan ganti rugidari konsumen, dengan alasan ia akan membentuk tim pengkaji ganti rugi terlebih dahulu. Inilah upaya pelaku usaha yang kelihatan agak licik dan kurang dapat diterima.

5) BUMN dan Perusahaan Daerah biasanya hanya sanggup memperbaiki, menyambung, menghidupkan lagi dan sejenisnya tanpa mau mengganti kerugian dalam bentuk materiil sesuai dengan isi perjanjian. Ini sebenarnya merupakan alasan klasik (yang mungkin sudah diantisipasi) oleh karena perjanjian tersebut sengaja dibuat untuk menghindarkan diri dari kemungkinan mengganti kerugian pelanggan (konsumen).

Beberapa alasan yang diajukan oleh pelaku usaha ini seolah-olah menunjukkan bahwa konsumen bersikap pasrah, apatis, dan tidak berdaya. Jalan keluar terbaik adalah bagaimana mengupayakan konsumen itu dapat lebih diberdayakan dalam menghadapi pelaku usaha.

b. Ketika berhadapan dengan pelaku usaha Swasta :

Kadang kala konsumen dibuat menjadi tidak berdaya oleh pelaku usaha swasta.Berikut diajukan upaya-upaya penyelesaian sengketa antara konsumen dengan pelaku usaha yang dilakukan oleh kalangan swasta, dengan beberapa pertimbangan.

1) Pelaku usaha swasta biasanya hanya mau mengganti kerugian sekecil mungkin walaupun ia sebenarnya senang juga untuk menyelesaikan masalahnya dengan konsumen secara kekeluargaan. Maksud kekeluargaan di sini adalah bahwa pelaku usaha tidak menutup kemungkinan menyelesaikan sengketa dengan konsumen lewat perantaraan mediator melalui proses mediasi. Dari data yang ada di LP2K Semarang, dari sekitar 70 kasus pengaduan yang diajukan kepadanya, ternyata cukup banyak juga pelaku usaha swasta yang menjadi tergugat (ada 32 kasus atau sekitar 45\%).

2) Pelaku usaha swasta biasanya juga berdalih bahwa aturan-aturan yang telah ada itulah yang hatus dipatuhi, padahal jelas-jelas bahwa peraturan tersebut sangat menguntungkan pelaku usaha dan di pihak lain sangat memberatkan konsumen. Kondisi ini terjadi oleh karena pelaku usahalah yang membuat dan menentukan isi perjanjian yang kemudian diajukan kepada konsumen. Oleh karenanya ia sangat berkepentingan dan mencari keuntungan sebanyak mungkin.

Ketidakberdayaan konsumen dapat tercipta ketika konsumen tidak 
kuasa berhadapan dengan pelaku usaha, sebab mereka berada pada posisi tawar yang rendah.Analisis yang dapat dikemukakan adalah bahwa ketidakberdayaan konsumen dalam menghadapi pelaku usaha itu oleh karena status sosial ekonomi mereka pada umumnya juga berada di bawah pelaku usaha. Dengan kata lain, bahwa ketidakberdayan tersebut berkaitan dengan tingkat kemiskinan yang menimpa dirinya.

Bagong Suyanto (1996:1) menyatakan, bahwa pada dewasa ini kemiskinan telah menjadi isu sosial sekaligus isu politik yang banyak dibicarakan di berbagai kalangan, baik kaum politisi maupun kaum cendekiawan. Menurut Bambang Sudibyo (dalam Awan Setya Dewanta, 1995 : 11), substansi kemiskinan adalah kondisi deprevasi terhadap sumber-sumber pemenuh kebutuhan yang berupa sandang, papan, dan pendidikan dasar.

\section{Pemberdayaan Konsumen dalam Penyelesaian Sengketa}

Upaya pemberdayaan terhadap konsumen dapat ditempuh lewat dua sisi, yakni yang berasal dari dalam diri konsumen dan pemberdayaan konsumen karena intervensi dari pihak luar untuk meningkatkan daya tawar konsumen.

a. Upaya-upaya pemberdayaan dari diri konsumen.

1) Perlunya peningkatan komunikasi hukum konsumen

Harus disadari bahwa kebanyakan konsumen yang masuk terhadap masalah ini bukanlah dari kalangan akademisi, oleh karenanya mereka juga tidak begitu paham dengan masalah hukum. Dalam kerangka inilah hendaknya konsumen tersebut lebih membekali diri sendiri dengan bertanya kepada yang lebih paham hukum, sering mendengarkan penyuluhan hukum baik lewat media elektronika maupun menghadiri dan mendengarkan secara langsung jika ada penyelenggaraan masalah termaksud.
2) Peningkatan pemahaman hukum secara umum

Hendaknya konsumen secara regular memahami, membaca, mengupayakan, mengorek lebih dalam bagaimana caranya agar ia lebih paham terhadap masalah yuridis. Banyak cara dapat dilakukan, misalnya membaca rubrik konsultasi hukum yang banyak dimuat di dalam koran atau majalah, tajuk rencana, dan sebagainya.

3) Pemahaman Undang-undang Perlindungan Konsumen

Dengan berlakunya Undang-undang Perlindungan Konsumen, berarti secara luas seluruh masyarakat diharapkan dapat mengetahui akan hak dan kewajibannya sebagaimana telah ditetapkan di dalam undang-undang. Upaya tersebut dapat tercapai jika masyarakat mau berusaha dan belajar sendiri.

b. Pengaruh pihak luar

Intervensi pihak luar termasuk peranan pemerintah atau institusi lain (termasuk Lembaga Swadaya Masyarakat) yang melakukan tindakantindakan nyata sehubungan dengan perlindungan konsumen. Dalam setiap langkah pemberdayaan, diharapkan peran dan posisi yang diambil oleh pemerintah maupun institusi lain dapat mengena dengan tepat. Aktor utama dalam pemberdayaan konsumen memang para konsumen itu sendiri, sedangkan pemerintah atau institusi lain berfungsi sebagai fasilitas atau fasilitator saja.

Dengan demikian, dalam pemberdayaan konsumen selain lembaga konsumen yang mewakili kepentingan masyarakat modern, masih ada produsen dan pemerintah. Artinya, dalam pemberdayaan konsumen selain oleh lembaga konsumen, juga menjadi tanggung jawab produsen dan pemerintah. Sekeras apapun upaya yang dilakukan oleh lembaga konsumen, tanpa ada komitmen yang sama dari produsen dan pemerintah dalam memberdayakan konsumen, tidak akan mendapatkan output yang optimal. 
Tindakan-tindakan yang dapat dilakukan oleh pemerintah atau instansi lain dalam rangka pemberdayaan konsumen antara lain :

1) Penyuluhan hukum

Banyak instansi yang dapat melakukan tindakan penyuluhan hukum demikian, mulai dari instansiinstansi tingkat pusat sampai daerah. Lembaga-lembaga seperti Badan Pembinaan Hukum Nasional (BPHN), Departemen Kehakiman, Kejaksaan, Lembaga-lembaga Perguruan Tinggi sampai kepada institusi swasta semacam Yayasan Lembaga Konsumen Indonesia (YLKI), Lembaga Pembinaan dan Perlindungan Konsumen (LP2K) sangat perlu dan secara periodik untuk memberikan penyuluhan hukum yang sangat berguna bagi masyarakat luas.

2) Acara dengar pendapat (talkshow)

LP2K Semarang cukup sering menyelenggarakan kontak pendengar dengan pemirsa lewat radio di Semarang. Kepada pendengar yang mengajukan pertanyaan secara langsung juga akan dijawab secara langsung, oleh karena acara tersebut adalah forum tanya jawab. Dengan adanya acara yang demikian pemahaman masyarakat secara umum (konsumen) terhadap masalah hukum akan lebih terbuka.

3) Surat pembaca

Beberapa surat kabar ternyata bersedia untuk menerima atau menampung masukan-masukan yang bahkan berupa keluhankeluhan yang dapat diajukan oleh siapapun tanpa kecuali. Dari jawaban pengasuh konsultasi hukum tersebut mestinya akan semakin menambah kejelasan bagi kalangan masyarakat umum yang kurang memahami terhadap masalah hukum (termasuk perlindungan konsumen).

4) Pendidikan konsumen

Tahun 1997 YLKI bekerja sama dengan USAID mengadakan dua kali kegiatan pendidikan konsumen di Jakarta berupa lokakarya dan diskusi. Tujuan lokakarya adalah : (1) mendapatkan masukan dari kalangan akademik dan profesional di bidang hukum mengenai pendidikan konsumen di fakultas hukum serta kemungkinan meningkatkan materi kurikulum pendidikan, baik dalam mata kuliah bidang hukum tersendiri atau tidak; (2) mendapatkan masukan kurikulum dasar tentang hukum konsumen (consumer law) di fakultas hukum; dan (3) mendapatkan masukan mengenai penyelesaian sengketa konsumen (consumer disputes) secara teoritis/praktis. Dengan pendidikan konsumen diharapkan dapat memberikan dorongan dan lebih memberdayakan konsumen.

5) Seminar hukum perlindungan konsumen

Seminar termasuk upaya mendongkrak konsumen agar lebih berdaya dan mempunyai posisi tawar yang tinggi.Beberapa perguruan tinggi baik negeri maupun swasta telah berkalikali menyelenggarakan seminar perlindungan konsumen. Hasil yang keluar adalah bahwa setelah mengikuti seminar demikian akan didapat kejelasan tentang segala hak dan kewajiban konsumen, bagaimana memposisikan diri agar mengimbangi posisi pelaku usaha dan sebagainya.

6) Siaran pers

LP2K Semarang kadang menyelenggarakan siaran pers. Pernah siaran pers tersebut ditujukan kepada pimpinan redaksi surat kabar, ketika pemerintah kota Semarang mengeluarkan kebijaksanaan tentang penarikan retribusi parkir "door to door." Menurut penilaian LP2K, kebijaksanaan tersebut akan banyak mengalami kendala dan akan menambah masalah baru. Kenyataan menunjukkan, baru tahap pendataan dan sosialisasi saja, banyak masyarakat yang mengeluh, apalagi setelah dilaksanakan, akan banyak yang protes. Siaran pers seperti ini demikian diharapkan 
akan dapat lebih meningkatkan/ memberdayakan masyarakat luas.

Oleh karena itulah ketika berlangsung upaya penyelesaian sengketa, hendaknya konsumen aktif berperan serta membantu mediator dengan melakukan pressure terhadap pelaku usaha agar mau memenuhi tuntutan konsumen. Dalam rangka pemberdayaan hukum bagi masyarakat luas, khususnya dalam rangka menciptakan masyarakat adil dan makmur, maka perlu pengkajian terus menerus, baik perangkat perundangundangan maupun dalam penegakan hukumnya, yakni seberapa jauh hukum dapat memberi dan mengembangkan hak-hak individu dan kelompokkelompok yang tidak berdaya. Artinya bahwa hukum harus mempunyai nilai praktis, nilai-nilai yang secara jelas tercermin dalam praktek penggunaan hukum dan pelaksanaannya.Karena itu perlu mengembangkan konsepkonsep dan teori-teori baik yang sudah ada maupun mengembangkan yang baru terus menerus dalam membangun pengetahuan sosial yang memungkinkan kita dapat memahami dunia yang terus menerus berubah. Dari sinilah kita dapat menarik suatu analisis bahwa peran mediator akan dapat meningkatkan posisi tawar konsumen agar seimbang dengan posisi tawar pelaku usaha.

Dalam format yang ideal, pemberdayaan konsumen secara simultan harus dilakukan dari dua arus. pertama, dari arus bawah, yakni adanya lembaga konsumen yang tumbuh dari bawah, kuat dan tersosialisasi secara baik dan merata di kalangan konsumen. Kedua, dari arus atas, adanya lembaga/ departemen dalam struktur kekuasaan yang secara khusus mengurusi masalah perlindungan konsumen.

Di dalam praktek, proses pemberdayaan dapat dilakukan dengan : (1) memberikan respons di antara klien dari valuasi negatif sehingga mereka dapat mengatasi masalah yang mereka hadapi; dan (2) memperoleh dukungan efektif-efisien dalam memecahkan berbagai masalah (Harry Hikmat, 2010 : 54-55).

\section{d. Simpulan}

Atas dasar temuan-temuan lapangan dan analisisnya, maka dapat ditarik kesimpulan dalam garis besarnya sebagai berikut :

1. Temuan lapangan menunjukkan, terdapat beberapa kondisi atau faktor yang menyebabkan konsumen tidak berdaya ketika berhadapan dengan pelaku usaha, antara lain : a) ketika berhadapan dengan pelaku usaha BUMN dan Perusahaan Daerah, terdapat banyak alasan yang dapat dikemukakan, yakni : posisi pelaku usaha yang demikian kuat menyebabkan seluruh aturan-aturan perjanjian dibuat oleh pelaku usaha secara sepihak, pelaku usaha selalu berkelit untuk memberikan ganti rugi dengan alasan tidak diatur di dalam peraturan, pelaku usaha selalu diwakili oleh stafnya dan bukan pimpinannya, pelaku usaha akan membentuk tim pengkaji ganti rugi, pelaku usaha hanya sanggup memperbaiki dan bukan mengganti; b) ketika berhadapan dengan pelaku usaha swasta, juga dikemukakan beberapa sebab, yakni : ganti kerugian yang diberikan pelaku usaha sangat kecil dibandingkan kerugian konsumen, pelaku usaha berkepentingan dan mencari keuntungan sebanyak mungkin atas peraturan yang dibuatnya.

2. Upaya pemberdayaan dapat ditempuh melalui dua jalur, yakni : a) dari diri konsumen sendiri dilakukan dengan cara : peningkatan komunikasi hukum konsumen, peningkatan pemahaman hukum secara umum, pemahaman terhadap Undang-undang Perlindungan Konsumen; b) pengaruh dari luar konsumen dilakukan dengan cara : penyuluhan hukum, acara dengar pendapat (talkshow), lewat surat pembaca, adanya pendidikan konsumen, seminar tentang perlindungan konsumen, dan siaran pers.

3. Secara garis besar, proses pelaksanaan atau praktek penyelesaian sengketa antara konsumen dengan pelaku usaha melalui tahap-tahap : Tahap pertama, menciptakan forum; tahap kedua, mengumpulkan dan membagi-bagi informasi, tahap ketiga, pemecahan masalah; dan tahap keempat, pengambilan keputusan.

\section{E. Saran}

1. Perlunya konsumen membekali diri dengan berbagai macam pengetahuan yang berkaitan dengan perlindungan konsumen, agar hak 
dan kewajibannya seimbang dengan hak dan kewajiban pelaku usaha. Di samping itu perlu juga mencermati dan memahami isi perjanjian yang disodorkan oleh pelaku usaha, agar ia dapat memahami segala apa yang tertuang di dalam dokumen perjanjian.

2. Ketika berlangsung upaya penyelesaian sengketa dengan konsumen, hendaknya pelaku usaha tidak bersikap arogan, angkuh dan mengedepankan "keangkuhannya", sehingga upaya yang dijembatani oleh mediator dapat berjalan dengan normal.

3. Hendaknya institusi yang peduli terhadap perlindungan konsumen lebih meningkatkan peran sertanya dalam upaya keberpihakan kepada konsumen dan berupaya meningkatkan posisi tawar konsumen agar bisa seimbang dengan posisi tawar pelaku usaha.

\section{daftar Pustaka}

Abdul Halim Barkatullah. 2010. Hak-hak Konsumen. Bandung : Nusa Media.

. 2009. perlindungan Hukum Bagi Konsumen dalam Transaksi E-commerce Lintas Negara di Indonesia. Yogyakarta : FH UII Press.

Adrian Sutendi. 2008. Tanggung Jawab produk dalam Hukum perlindungan Konsumen. Bogor : Ghalia Indonesia.

Ahmadi Miru. 2011. prinsip-prinsip perlindungan Hukum Bagi Konsumen di Indonesia. Jakarta : PT Radja Grafindo Persada. Persada.

A. Sonny Keraf. 1998. Etika Bisnis Tuntutan dan relevansinya. Yogyakarta : Kanisius.

Awan Setya Dewanta dkk (ed). 1995. Kemiskinan dan Kesenjangan di Indonesia. Yogyakarta : Aditya Media.

Bagong Suyanto.1996. perangkap Kemiskinan : problem dan Strategi pengentasannya dalam pembangunan Desa. Yogyakarta : Aditya Media.

Bambang Sunggono. 2011. Metodologi penelitian Hukum. Jakarta : PT Raja Grafindo Persada.

Bilson Simamora. 2001. remarketing for Business recovery. Jakarta : PT Gramedia Pustaka Utama.

Robert Chambers. 1983. rural Development : putting the Last First. New York : Longman.

Djam'an Satori \& Aan Komariah. 2012. Metodologi penelitian Kualitatif. Bandung : Alfabeta.

Djunaidi Ghony, M \& Fauzan Almanshur. 2012. Metodologi penelitian Kualitatif. Yogyakarta : AR-RUZZ MEDIA.

Esmi Warassih. 1993. Metodologi penelitian Bidang IImu Humaniora. Semarang : Bagian Humas FH Undip.

Harry Hikmat. 2010. Strategi pemberdayaan Masyarakat. Bandung : Humaniora Utama Press.

HB Sutopo. 1990. Metodologi penelitian Kualitatif Bagian II. Surakarta : UNS Press.

Husni Syawali \& Neni Sri Imaniyati (ed). 2000. Hukum perlindungan Konsumen. Bandung : Mandar Maju.

John W. Creswell. 2012. Research Design Pendekatan Kualitatif, Kuantitatif, dan Mixed(terjemahan Judul asli Research Design Qualitative, Quantitative, and Mixed Methods Approaches oleh Achmad Fawaid). Yogyakarta : Pustaka Pelajar.

Lexy J. Moleong. 2005. Metodologi penelitian Kualitatif. Bandung : PT Remaja Rosdakarya. 
M. Ali Mansyur. 2007. perlindungan Konsumen yang responsif Kontemporer : gagasan Mewujudkan Konsumen yang Bermartabat dan produsen yang Bertanggung Jawab. Semarang : Unissula Press.

Mathew B Miles \& Michael A. Huberman. 1992. Analisis Data Kualitatif. Jakarta : UI Press.

Mukti Fajar ND \&Yulianto Achmad. 2010. Dualisme penelitian Hukum Normatif \& Empiris. Yogyakarta : Pustaka Pelajar.

NHT Siahaan. 2005. Hukum Konsumen : perlindungan Konsumen dan Tanggung Jawab produk. Jakarta : Panta Rei.

Onny S Prijono \& AMW Pranarka. 1996. pemberdayaan : Konsep, Kebijakan dan Implementasi. Jakarta : CSIS.

Sanusi Bintang \& Dahlan. 2000. pokok-pokok Hukum Ekonomi dan Bisnis. Bandung : PT Citra Aditya Bakti.

Sri Redjeki Hartono. 2000. Kapita Selekta Hukum Ekonomi. Bandung : CV Mandar Maju.

Sugiyono.2012. Memahami penelitian Kualitatif (Dilengkapi contoh proposal dan Laporan penelitian). Bandung : Alfabeta.

2012. Metode penelitian Kuantitatif Kualitatif dan r\&D. Bandung : Alfabeta.

Yusuf Shofie. 2000. perlindungan Konsumen dan Instrumen-instrumen Hukumnya. Bandung : PT Citra Aditya Bakti.

(ed). 1998. percakapan tentang perlindungan Konsumen dan Kurikulum Fakultas Hukum. Jakarta : YLKI - USAID.

14 Yustisia Vol.2 No.3 September - Desember 2013 Pemberdayaan dan Perlindungan Hukum ... 